\title{
INVESTIGATION OF CHANNELS OF Cs-137 AND K TRANSFER FROM SOIL TO PLANT UNDER NATURAL CONDITIONS WITH OPTICAL AND GAMMA SPECTROMETRY
}

\author{
V.V. PROROK, L.A. BULAVIN, L.V. POPERENKO
}

PACS 71.20.Nr, 72.20.Pa (C) 2012
Taras Shevchenko National University of Kyiv, Faculty of Physics

(2, Prosp. Academician Glushkov, Kyiv 03022, Ukraine; e-mail: prorok@ univ. kiev. ua)
The aim of this work is to investigate the channels of transfer of Cs and potassium from soil to plants under natural conditions. Different rapidly maturing plants were grown simultaneously at the same experimental sites under natural conditions at the Chornobyl Exclusion Zone. Roots of the plants were side by side in soil. During two seasons, we selected samples of the plants and soils several times every season. After every selection, the contents of ${ }^{137} \mathrm{Cs}$ and $\mathrm{K}$ in the plant and in the soil solution extracted from the samples of soils were measured. Experimental data are analyzed. All the investigated plants at all our experimental sites uptake ${ }^{137} \mathrm{Cs}$ mainly via low-affinity cation channels at any composition of the soil solution and the soil humidity. The plant uptakes potassium mainly via low-affinity cation channels if the plant has enough potassium. At the potassium starvation, the plant uses also the high-affinity potassium channel for the potassium uptake. There is the high discrimination against ${ }^{137} \mathrm{Cs}$ in this case.

\section{Introduction}

There is always the possibility of an accident "a la Chornobyl" or "a la Fukusima" for all countries with nuclear power stations. Moreover, soil may be polluted with radionuclides from other sources. So, the problem of the prediction of the ${ }^{137} \mathrm{Cs}$ concentration in plants from contaminated land with a certain type of soil is actual for any country. This problem is not solved today (see, e.g., [1]). Many researchers have tried to study the correspondence between the ${ }^{137} \mathrm{Cs}$ concentration in soils and the ${ }^{137} \mathrm{Cs}$ concentration in plants (e.g., review [2]). Unfortunately, the correspondences are correlations, but are not laws. Moreover, the recent published data [3-7] show that, at different times, the same plants from the same site differ in the ${ }^{137} \mathrm{Cs}$ concentration near 50 times. In others words, the ${ }^{137} \mathrm{Cs}$ concentration in soil does not determine the ${ }^{137} \mathrm{Cs}$ concentration in the plant under natural conditions.

Many researchers connect the ${ }^{137} \mathrm{Cs}$ uptake by a plant with the potassium uptake. The idea that the higher plant root cells contain at least two separate $\mathrm{K}^{+}$uptake systems is now indisputably established. These two systems, with low and high affinities, fundamentally differ in their mechanisms and work simultaneously. The low-affinity system (passive) is dominant at millimolar potassium external concentrations and the high-affinity system is dominant at micromolar potassium external concentrations $[8,9]$. The cross-over point defining the potassium external concentration such that one of the systems is dominant at either side of it has been shown to be in the region of 0.3 to $1 \mathrm{mM}$ [8].

Nonselective cation channels in plants are described in [10]. They are classified by the basis voltage sensitivity, activation by cytosolic $\mathrm{Ca}^{2+}$, activation by amino acids, notably glutamate, and mechanosensitivity.

According to [11], Cs is transferred to plants via enter potassium channels, voltage nonsensitive cation channels, $\mathrm{K}^{+} / \mathrm{H}^{+}$transporter, and calcium channels. From a plant to soil, Cs moves via potassium-out channels. Under natural conditions, the Cs transfer from soil to a plant occurs mostly via voltage nonsensitive cation channels.

It was concluded in $[12,13]$ after investigations of $A r a-$ bidopsis that Cs enters a plant via voltage nonsensitive cation channels at the potassium depletion. If there is the potassium starvation of a plant, the essential part of the Cs transfer to the plant occurs via a $\mathrm{K}^{+} / \mathrm{H}^{+}$transporter.

It is affirmed at [14] that Cs enters a plant only via the potassium transport system $\left(\mathrm{K}^{+} / \mathrm{H}^{+}\right.$transporter and potassium channels). There is a slight discrimination against $\mathrm{Cs}$, if the external potassium concentration is less than $0.3 \mathrm{mM}$, and there is a strong discrimination against $\mathrm{Cs}$, if the external potassium concentration is higher (potassium channels are prevailing).

The above-mentioned investigations were carried mostly under artificial conditions. 


\section{Experimental}

We carried out our investigations under field conditions and studied the growth at three experimental field sites with different types of soil using different plants. The sites are situated at a distance of $30 \mathrm{~km}$ from the Chornobyl Nuclear Power Plant in the north-east direction.

site A - based on glacial-water sand, soddy podzol, middle podzol, silt sand soil; average pollution with Cs-137 is near $980 \mathrm{kBq} / \mathrm{m}^{2}$;

site $\mathbf{B}$ - based on decomposed middle thick sedge, rush and wood peat, low-lying type peat soil; average pollution with $\mathrm{Cs}_{\mathrm{s}}-137$ is near $13,000 \mathrm{kBq} / \mathrm{m}^{2}$;

site $\mathbf{C}$ - based on glacial-water sand loam, soddy podzol, middle podzol sand loam with the signs of temporal excess humidification of soil; average pollution with Cs-137 is near $620 \mathrm{kBq} / \mathrm{m}^{2}$.

We mixed together and sowed rapidly maturing plants at sites A, B, and C that are as divergent from each other as possible. These are radish (raphanus sativus), salad (lactuca sativa), and watercress (lepidium sativum). The plants were sowed at each experimental site several times during each season. Parameters of the soil solution for all plants were the same, as they were growing jointly at the same site at the same time. We selected samples several times every season. Every time, we harvested samples of soils, samples of the sowed plants, (if they had grown), and samples of wild plants. We investigated the samples of plants and the corresponding soil solution. As a rule, we selected whole plants. Sometime, we took only a part of the plant (leaves or roots). We harvest all plants at the every experimental site at every sample selection. But we did not harvest sprouts of plants, so they can continue to grow. The mass of selected plants of every kind was in the range 5 g-500 g. The plants were sampled before blossoming and were washed and dried. The soil solution was extracted from soil with the use of a centrifuge RS-6 (former USSR) with a centripetal acceleration of $3,000 \mathrm{~g}$. We extracted soil solutions from some samples immediately. If a sample of soil was too dry for the extraction of a soil solution, we extracted it after the addition of distilled water to the sample and treating it with a rotator for $1 \mathrm{~h}$. Our estimation for all our investigated soils show that the addition of water to soil changes the ${ }^{137} \mathrm{Cs}$ concentration in a soil solution by at most $5 \%$, if the soil moisture do not exceed the moisture of watersaturated soil. As a rule, we extracted near $200 \mathrm{ml}$ of a soil solution at every extraction. The centrifuged solution was filtered through a glass filter Whatman GF/A and through a filter TU 6-09-1678-86 (former USSR). The soil solutions after the filtration were clear. To conserve the obtained soil solution, we added nitric acid to it in the proportion of $1 \mathrm{ml}$ of concentrated nitric acid per $500 \mathrm{ml}$ of a soil solution and heated it to boiling.

We determined the moisture of soil, $h$, as the mass of water contained in $1 \mathrm{~cm}^{3}$ of soil with an experimental error of $10 \%$.

We measured the ${ }^{137}$ Cs content (activity) per unit of mass in dried plants and in soil solutions with a gammaspectrometer ORTEC with experimental errors of 5\%$15 \%$.

The method was described in more details in [3-5].

The data for sites A, B, and C are represented in Tables $1-3$.

In the tables, we show the soil solution content per unit volume of soil, (humidity) $h$ for all experimental sites and all selection dates, sample selection date, kind of species, concentrations of potassium and ${ }^{137} \mathrm{Cs}$ in the plants $(\mathrm{p})$ and the corresponding soil solution (ss), $r=\left({ }^{137} \mathrm{Cs} / \mathrm{K}\right)_{p} /\left({ }^{137} \mathrm{Cs} / \mathrm{K}\right)_{s s}$, where $\left({ }^{137} \mathrm{Cs} / \mathrm{K}\right)_{p}$ - ratio of concentrations of ${ }^{137} \mathrm{Cs}$ and $\mathrm{K}$ in the plant, $\left({ }^{137} \mathrm{Cs} / \mathrm{K}\right)_{s s}$ - ratio of concentrations of ${ }^{137} \mathrm{Cs}$ and $\mathrm{K}$ in the corresponding soil solution, and the concentration of dissolved potassium in the soil (product of the potassium concentration in the soil solution and the soil solution content per unit volume of soil) $C_{k}$. Experimental data on humidity $h$ and the concentrations of potassium and ${ }^{137} \mathrm{Cs}$ in plants and in the correspondent soil solution were represented in $[3-5]$. We can see that $r$ is the ratio of the concentration coefficients plants:soil solution for ${ }^{137} \mathrm{Cs}$ and $\mathrm{K}$ in the investigated samples, too. Experimental errors for all data did not exceed $10 \%$.

We can see from Table 2 that $C_{k}>0.00169 \mathrm{mg} / \mathrm{cm}^{3}$ at site $\mathrm{B}$ in all cases, and the value of $r$ was near 1 in all cases.

We can see from Table 3 that $C_{k}<0.002 \mathrm{mg} / \mathrm{cm}^{3}$ at site $\mathrm{C}$ in all cases, except for one case, and $r$ is less than 1 by many times. In one case, $C_{k}=0.0045$, and $r$ was near 1.

\section{Discussion}

For all the investigated plants and soils at the investigating stage of growth (before blossoming) at concentrations of dissolved potassium in soil $C_{k}>(0.002-$ $0.004) \mathrm{mg} / \mathrm{cm}^{3}$, the transition of caesium and potassium from soil to plants via low-affinity channels is prevailing. 
T a b l e 1. Data for site A

\begin{tabular}{|c|c|c|c|c|c|c|}
\hline$h, \mathrm{~g} / \mathrm{cm}^{3}$ & Date & Sample & $\mathrm{K}, \mathrm{mg} / \mathrm{g}$ & ${ }^{137} \mathrm{Cs}, \mathrm{Bq} / \mathrm{kg}$ & $\left({ }^{137} \mathrm{Cs} / \mathrm{K}\right)_{p} /\left({ }^{137} \mathrm{Cs} / \mathrm{K}\right)_{s s}$ & $C_{K}, \mathrm{mg} / \mathrm{cm}^{3}$ \\
\hline 0.12 & 09 June 2002 & Soil solution & 0.0070 & 8.0 & & \\
\hline$-"{ }^{\prime}-$ & 09 June 2002 & Phleum pratense & 20.96 & 5276 & 0.220 & 0.00084 \\
\hline 0.73 & 22 June 2002 & Soil solution & 0.0292 & 8.0 & & \\
\hline 0.069 & 22 June 2002 & Roots of raphanus sativus & 64.70 & 1746 & 0.099 & 0.00201 \\
\hline$-{ }^{\prime \prime}-$ & 22 June 2002 & Leaf of raphanus sativus & 43.49 & 2018 & 0.169 & 0.00201 \\
\hline$-"-$ & 22 June 2002 & Lepidium sativum & 48.30 & 4540 & 0.343 & 0.00201 \\
\hline 0.73 & 14 July 2002 & Soil solution & 0.0282 & 7.9 & & \\
\hline 0.17 & 14 July 2002 & Phleum pratense & 12.15 & 5725 & 1.682 & 0.00479 \\
\hline$-"$ - & 14 July 2002 & Stachys palustris & 27.67 & 10206 & 1.317 & 0.00479 \\
\hline 0.32 & 08 June 2003 & Soil solution & 0.0214 & 4.9 & & \\
\hline 0.018 & 08 June 2003 & Raphanus sativus & 52.34 & 216 & 0.018 & 0.000385 \\
\hline$-"-$ & 08 June 2003 & Lepidium sativum & 38.28 & 265 & 0.030 & 0.000385 \\
\hline$-{ }^{\prime \prime}-$ & 08 June 2003 & Lactuca sativa & 52.617 & 672 & 0.056 & 0.000385 \\
\hline$-"-$ & 08 June 2003 & Stachys palustris & 29.774 & 606 & 0.089 & 0.000385 \\
\hline 0.34 & 13 July 2003 & Soil solution & 0.0217 & 3.2 & & \\
\hline 0.039 & 13 July 2003 & Lactuca sativa & 47.39 & 585 & 0.084 & 0.000846 \\
\hline$-"-$ & 13 July 2003 & Polygonum hydropiper & 34.07 & 679 & 0.135 & 0.000846 \\
\hline$-"{ }^{\prime}-$ & 13 July 2003 & Stachys palustris & 32.35 & 1722 & 0.361 & 0.000846 \\
\hline
\end{tabular}

T a b l e 2. Data for site B

\begin{tabular}{|c|c|c|c|c|c|c|}
\hline$h, \mathrm{~g} / \mathrm{cm}^{3}$ & Date & Sample & $\mathrm{K}, \mathrm{mg} / \mathrm{g}$ & ${ }^{137} \mathrm{Cs}, \mathrm{Bq} / \mathrm{kg}$ & $\left({ }^{137} \mathrm{Cs} / \mathrm{K}\right)_{p} /\left({ }^{137} \mathrm{Cs} / \mathrm{K}\right)_{s s}$ & $C_{K}, \mathrm{mg} / \mathrm{cm}^{3}$ \\
\hline 0.59 & 09 June 2002 & Soil solution & 0.0045 & 61 & & \\
\hline$-"{ }^{\prime}-$ & 09 June 2002 & Urticaceae dioica & 11.42 & 609400 & 3.937 & 0.00266 \\
\hline$-{ }^{\prime \prime}-$ & 09 June 2002 & Polygonum hydropiper & 23.56 & 606600 & 1.899 & 0.00266 \\
\hline 0.80 & 22 June 2002 & Soil solution & 0.007 & 40.8 & & 0.00448 \\
\hline 0.64 & 22 June 2002 & Roots of raphanus sativus & 39.29 & 240760 & 1.051 & 0.00448 \\
\hline$-"$ - & 22 June 2002 & Leaf of raphanus sativus & 26.84 & 414700 & 2.651 & 0.00448 \\
\hline$-"$ - & 22 June 2002 & Lepidium sativum & 39.8 & 758800 & 3.271 & 0.00448 \\
\hline$-{ }^{\prime}-$ & 22 June 2002 & Polygonum hydropiper & 18.71 & 305700 & 2.803 & 0.00448 \\
\hline 0.80 & 14 July 2002 & Soil solution & 0.0047 & 95 & & \\
\hline 0.36 & 14 July 2002 & Urticaceae dioica & 6.704 & 230900 & 1.704 & 0.00169 \\
\hline$-"{ }^{\prime}-$ & 14 July 2002 & Motley grass & 9.522 & 617500 & 3.208 & 0.00169 \\
\hline 0.35 & 08 June 2003 & Soil solution & 0.0217 & 44.3 & & \\
\hline 0.12 & 08 June 2003 & Lactuca sativa & 31.28 & 35911 & 0.562 & 0.00260 \\
\hline$-{ }^{\prime}-$ & 08 June 2003 & Blades of elytrigia repens & 17.03 & 47741 & 1.373 & 0.00260 \\
\hline$-{ }^{*}-$ & 08 June 2003 & Urticaceae dioica & 12.79 & 55260 & 2.116 & 0.00260 \\
\hline$-"$ - & 08 June 2003 & Polygonum hydropiper & 17.5 & 118888 & 3.328 & 0.00260 \\
\hline 0.18 & 13 July 2003 & Soil solution & 0.020 & 27 & & \\
\hline 0.18 & 13 July 2003 & Lactuca sativa & 40.25 & 64924 & 1.195 & 0.0036 \\
\hline$-"$ - & 13 July 2003 & Raphanus sativus & 49.78 & 26130 & 0.389 & 0.0036 \\
\hline$-"$ - & 13 July 2003 & Polygonum hydropiper & 24.06 & 54348 & 1.673 & 0.0036 \\
\hline$-{ }^{*}-$ & 13 July 2003 & Blades of elytrigia repens & 27.18 & 36505 & 0.995 & 0.0036 \\
\hline
\end{tabular}

For $C_{k}<(0.002-0.004) \mathrm{mg} / \mathrm{cm}^{3}$, the plant uses a highaffinity channel for the potassium uptake. The caesium uptake by the plant depends slightly on the content of others elements in the soil solution. It is approximately proportional to the concentration of dissolved caesium in soil in all cases [3-5]. The less the concentration of dissolved potassium in soil, the higher the part of potassium transferred to a plant via a high-affinity channel. The higher the part of potassium transferred to a plant via the high-affinity channel, the less the Cs concentra- 


\begin{tabular}{|c|c|c|c|c|c|c|}
\hline$h, \mathrm{~g} / \mathrm{cm}^{3}$ & Date & Sample & $\mathrm{K}, \mathrm{mg} / \mathrm{g}$ & ${ }^{137} \mathrm{Cs}, \mathrm{Bq} / \mathrm{kg}$ & $\left({ }^{137} \mathrm{Cs} / \mathrm{K}\right)_{p} /\left({ }^{137} \mathrm{Cs} / \mathrm{K}\right)_{s s}$ & $C_{K}, \mathrm{mg} / \mathrm{cm}^{3}$ \\
\hline 0.47 & 09 June 2002 & Soil solution & 0.0475 & 4.8 & & \\
\hline 0.095 & 09 June 2002 & Barbarea vulgaris & 32.26 & 5212 & 1.599 & 0.00451 \\
\hline -"- & 09 June 2002 & Convolulas arvensis & 36.52 & 7772 & 2.106 & 0.00451 \\
\hline 0.21 & 08 June 2003 & Soil solution & 0.0475 & 1.9 & & \\
\hline$<0.014$ & 08 Jule 2003 & Leafs of raphanus sativus & 40.203 & 82 & 0.051 & $<0.000665$ \\
\hline$<0.014$ & 08 Jule 2003 & Convolulas arvensis & 34.455 & 93 & 0.067 & $<0.000665$ \\
\hline 0.17 & 13 Jule 2003 & Soil solution & 0.0528 & 7.1 & & \\
\hline$<0.031$ & 13 Jule 2003 & Leafs of raphanus sativus & 50.7 & 164 & 0.024 & $<0.00163$ \\
\hline$<0.031$ & 13 Jule 2003 & Convolulas arvensis & 38.09 & 165 & 0.032 & $<0.00163$ \\
\hline$<0.031$ & 13 Jule 2003 & Barbarea vulgaris & 31.61 & 105 & 0.025 & $<0.000846$ \\
\hline
\end{tabular}

tion in a plant. At low contents of a soil solution in soil, the potassium high-affinity channel is prevailing, and the caesium concentration in a plant is far less than that in the case of a high content of the soil solution. For example, a peat soil contains high amounts of a soil solution, and the concentration of caesium in the growing plants is high.

We can see that the potassium transfer via the highaffinity channel is prevailing sometimes at rather high potassium concentrations in the soil solution (but the soil humidity is small). Sometime, the potassium transfer via the low-affinity channel is prevailing at low potassium concentrations in the soil solution (but the soil humidity is high). The product of the potassium concentration in the soil solution and the soil solution content in unit volume of soil (concentration of dissolved potassium in soil) determine more exactly the cross point of a prevailing low- or high-affinity channel, than the potassium concentration in the soil solution. Moreover, we think that it would be more correct to affirm that the prevailing low- or high-affinity channel is determined by needs of a plant in potassium. If potassium transferred via the low-affinity channel is not sufficient for a plant, the plant takes potassium via the high-affinity channel. Needs of a plant in potassium are determined partially by the kind of a plant, by the stage of growth, by the content of potassium in a plant, and by the content of other macro- and microelements in soil.

There are many channels for the potassium transfer to plants [6-8]. We cannot identify them on the basis of our data. But we can determine whether it is the highor low-affinity channel in the every case.

We can see from our data that the start moment of the dominance of a high- or low-affinity channel of the potassium uptake by a plant at the given potassium concentration in the soil solution strongly depends on the soil solution content in unit volume of soil. Let us try to explain this. Soil pores are filled or partly filled by a soil solution under natural conditions. The larger the volume of pores in soil, the greater the soil solution can be absorbed. A plant uptakes nutrition elements via root epidermis. The higher the soil solution content in unit volume of soil, the larger the area of root epidermis contacts with a soil solution. As is seen from Tables 1-3, the larger the area of root epidermis in contact with a soil solution, the more the potassium and caesium is uptaken by a plant via the low-affinity (not selective, passive) channel. These values are approximately proportional. So, the higher the soil solution content in unit volume of soil, the less the potassium from a soil solution is uptaken by a plant to compensate the potassium deficiency. In this case, the plant uses the high-affinity (selective) channel of potassium uptake. There is a high discrimination against caesium, when the high-affinity channel is essentially prevailing. We can conclude that, for all the investigated experimental sites, kinds of plants, and the times, caesium is transferred to plants mostly via the low-affinity channel. This does not depend on the soil solution content and the soil humidity.

\section{Conclusion}

All the investigated plants at all experimental sites uptake ${ }^{137}$ Cs mainly via low-affinity cation channels at any composition of the soil solution and the soil humidity. The plant uptakes potassium mainly via lowaffinity cation channels if the plant has enough potassium. At the potassium starvation, the plant also uses the high-affinity potassium channel for the potassium uptake. There is a high discrimination against ${ }^{137} \mathrm{Cs}$ in this case.

1. N. Waegeneers, T. Sauras-Year, Y. Thiry et al., J. Env, Radioact. 100, 439 (2009). 
2. S. Ehlken and G.J. Kirchner, Env. Radioact. 58, 97 (2002).

3. V.V. Prorok, C.F.V. Mason, S.F. Timofeyev et al., Bulletin of Univ. of Kyiv. Phys. and Math., No. 3, 407 (2004).

4. V.V. Prorok, C.F.V. Mason, V.A. Ageyev et al., in Proc. of WM'06. Session 66. Tucson (Arizona), 26 February2 March 2006, WM06/66.html.

5. L.A. Bulavin, V.V. Prorok, V.A. Ageyev et al., Dopov. Nats. Akad. Nauk Ukr., No. 8, 197 (2007).

6. L.A. Bulavin, V.V. Prorok, and L.V. Poperenko, Dopov. Nats. Akad. Nauk Ukr., No. 1, 173 (2011).

7. V.V. Prorok, C.F.V. Mason, L.A. Bulavin, and L.V. Poperenko, in International Conference "Twenty-Five Years after Chernobyl Accident. Safety for the Future," April 20-22, 2011, Kyiv (Kyiv, 2011), p. 182.

8. F.J.M. Maathuis and D. Sanders, Physiol. Plant. 96, 158 (1996).

9. F.J.M. Maathuis, A.M. Ichida, D. Sanders et al., Plant Physiol. 114, 1141 (1997).

10. V. Demidchik, R.J. Davenport, and M. Tester, Annu. Rev. Plant Biol. 53, 67 (2002).

11. J.W. Philip and M.R. Broadley, New Phytol. 147, 241 (2000).

12. C.R. Hampton, M.R. Droadlug, and P.J. White, Nukleonika 50 (Supplement 1), S3 (2005).
13. Zhi Qi, C.R. Hampton, Ryoung Shin et al., J. Exp. Bot. 59, 595 (2008).

14. Y-G. Zhu and E. Smolders, J. Exp. Bot. 51, 1635 (2000).

Received 21.09.11

ДОСЛІДЖЕННЯ КАНАЛІВ НАДХОДЖЕННЯ ${ }^{137} \mathrm{Cs}$ ТА К З ГРУНТУ ДО РОСЛИНИ У ПРИРОДНИХ

УМОВАХ ЗА ДОПОМОГОЮ ОПТИЧНОЇ TA ГАММА-СПЕКТРОСКОПIї

В.В. Пророк, Л.О. Булавін, Л.В. Поперенко

$\mathrm{P}$ е $з$ ю м е

Мета цієї роботи - дослідити канали надходження цезію та калію з грунту до рослин у природних умовах. Різні швидковиростаючі рослини росли одночасно на тих самих експериментальних ділянках у природних умовах у Чорнобильській зоні відчуження. Корені всіх цих рослин знаходилися поряд у грунті. Протягом двох вегетаційних сезонів ми відбирали зразки рослин та грунтів кілька разів за сезон. Після кожного відбору зразків визначали вміст ${ }^{137} \mathrm{Cs}$ та K у кожній рослині та в екстрагованому з відібраного грунту грунтовому розчині. Експериментальні дані проаналізовано. В усі досліджені рослини на всіх експериментальних ділянках ${ }^{137} \mathrm{Cs}$ надходив переважно по низькоселективних каналах за будь-якого складу грунтового розчину та вологості грунту. Калій надходив до рослин переважно по низькоселективних каналах, якщо рослина мала достатньо калію. При дефіциті калію у рослині вона використовувала також високоселективний канал надходження калію. При цьому спостерігалася сильна дискримінація ${ }^{137} \mathrm{Cs}$. 